\title{
A transdisciplinary approach on the energy efficient retrofitting of a historic building in the Aegean Region of Turkey
}

\author{
Cem Doğan Şahin ${ }^{\mathrm{a}}$, Zeynep Durmuş Arsan ${ }^{\mathrm{b}}$, Selim Sarp Tunçoku ${ }^{\mathrm{c}}$, Tor Broström ${ }^{\mathrm{d}}$, \\ Gülden Gökçen Akkurtt ${ }^{\mathrm{a}, *}$
}

${ }^{a}$ Energy Engineering Program, Izmir Institute of Technology, Izmir, Turkey

${ }^{\mathrm{b}}$ Department of Architecture, Izmir Institute of Technology, Izmir, Turkey

c Department of Architectural Restoration, Izmir Institute of Technology, Izmir, Turkey

d Department of Art History-Conservation, Uppsala University Campus Gotland, Visby, Sweden

\section{A R T I C L E I N F O}

\section{Article history:}

Received 26 August 2014

Received in revised form 3 March 2015

Accepted 7 March 2015

Available online 14 March 2015

\section{Keywords:}

Energy efficiency

Historic buildings

Retrofitting

Cultural heritage value

Calibration

Building energy simulation

\begin{abstract}
A B S T R A C T
Buildings account for $40 \%$ of total energy consumption in the European Union, yet at the same time they have considerable energy saving potentials. Historic buildings should be treated different from contemporary ones when it comes to energy improvements. The specifications which underline historical, sociocultural and architectural values require certain care during realization of energy saving implementations to sustain these values. The purpose of this study is to demonstrate how the energy efficient retrofitting in historic buildings should be managed in a transdisciplinary approach with a case study conducted on the historic building in İmir-Turkey. A detailed building energy simulation tool was used to determine the impacts of energy efficient retrofits. The actual energy consumption of case building was based on the utility bills regarding electricity and heating fuel consumption. Building energy simulation tool was calibrated by comparing the measured and simulated indoor air temperatures and total energy consumptions. The inappropriate retrofits, which contradict to the cultural heritage values, were eliminated with a transdisciplinary approach. Later appropriate retrofits were gathered into three packages to evaluate their effects on the energy consumption. The results show that energy saving of more than $34 \%$ can be obtained without damaging the heritage values.
\end{abstract}

(c) 2015 Elsevier B.V. All rights reserved.

\section{Nomenclature \\ MBE mean bias error (\%) \\ RMSE root-mean-squared-error (\%) \\ CV(RMSE) coefficient of variance of the root-mean-squared- error (\%) \\ $t_{i} \quad$ simulated value \\ $o_{i} \quad$ measured value \\ $n \quad$ number of observations \\ $A_{\text {period }}$ average of the measured values}

\footnotetext{
* Corresponding author. Tel.: +90 232750 6706; fax: +90 2327506701

E-mail address: guldengokcen@iyte.edu.tr (G.G. Akkurt).
}

\section{Introduction}

The total primary energy consumption in the world has risen with developing technology and increasing population. From 1992 to 2012 , it sharply rose by $52 \%$ [1]. Finding alternative strategies have become an essential issue to overcome this increasing energy demand. Generally European countries have been seeking and investing on alternative energy sources such as wind, solar and bio fuels to substitute the share of fossil-fuel-driven energy sector while promoting on the efficient use of energy [2].

Turkey officially began paying more attention to energy efficiency in buildings with the standard on "TS825-Thermal Insulation Requirements for Buildings" in 2000 [3]. The Directive on Building Energy Performance (BEP-TR) accelerated the energy certification procedure which obligates that the walls, floors, windows and roofs of the buildings built after 2000 must have lower overall heat transfer coefficient [4]. Considering that $67 \%$ of Turkish population live in the buildings built before 2000 and the buildings account for $35 \%$ of primary energy consumption of 
Turkey, one can assert that buildings have considerable energy saving potential $[5,6]$.

The BEP-TR refers to existing and new buildings. However, almost no specific attention on energy efficient retrofitting of historic buildings has been paid. The authority, who is responsible for the preservation of cultural and architectural heritage in Izmir, is the 'Number 1-İzmir Regional Board for the Conservation of Cultural and Natural Assets' connected to the 'Ministry of Culture and Tourism, Conservation Council of Immobile Cultural and Natural Assets'. The Board prioritizes the preservation of original characteristics of the heritage buildings and stipulates the minimum intervention in case they will be re-used or given a new function. In terms of historical, architectural, structural and material properties, high variety of historic buildings in the country makes difficult to constitute regulations for their energy performance to meet contemporary comfort conditions. Therefore, Clause $2 / c ̧$ of BEP-TR simply says that energy efficient retrofits and interventions in buildings having heritage value ought to be done in cooperation with authorized official authorities and without affecting the historical heritage value of the buildings, reflecting the Energy Performance of Buildings Directive (EPBD) [2]. Nevertheless, this is a general statement and does not provide any further instructions regarding the way historic buildings should be treated. Therefore, energy efficiency applications in historic buildings require special attention since the number of studies in Turkey is relatively insufficient [7].

The building stock in any country has a range from the monumental to contemporary buildings. A key step is to give a definition of historic buildings in order to identify those buildings that should be treated separately and with awareness. At this point, giving an answer to the question "What is the heritage value?" can clarify and enlighten the possible misunderstandings behind it. Historic buildings have a significance regarding the tangible and intangible heritage such as prominent architectural and aesthetic values, connections with historic communities and events, evidences of technical progression, characteristics of social history and associations with other building heritage values [8]. Basically, any tangible and intangible element giving identity and character to the building can be counted as a heritage value, which is primarily categorized as evidential, historical, aesthetic and communal value [8].

The general aim of this study is to investigate energy efficient retrofitting (EER) interventions in historic case study building while taking into account of heritage values. The building that was chosen as case study is Basmane Neighborhood Centre (Basmane Semt Merkezi), which is located at Basmane district in İzmir, Turkey. The building was built by Tabak Family in İzmir by the end of the 19th century. Later it was donated to the Prime Ministry General
Directorate of Social Services and Child Protection to serve as a dormitory for the orphans. Konak Municipality financially undertook a restoration project which was prepared and supervised by Architectural Restoration Department of İzmir Institute of Technology, İzmir-Turkey. The restoration work was completed in 2007. Currently, Basmane Semt Merkezi is used to educate illiterate women and deliver training courses of handcrafts, embroidery, marbling etc.

This study primarily contributes to the current literature by showing how the energy retrofits in historical buildings should be managed using a validated and calibrated building energy simulation tool integrated with a systematic and transdisciplinary strategy. Furthermore, the proposed method will be applied in a case study and interpreted from the perspective of energy saving, impact on heritage value and overall heat transfer coefficient requirement of "TS825-Thermal Insulation Requirements for Buildings" standard. This study will be the first in Turkey which considers energy efficient retrofitting in historical buildings via a transdisciplinary approach.

\section{The case building: Basmane neighborhood centre (Basmane Semt Merkezi)}

The building of Basmane Semt Merkezi is placed in the Basmane district of İzmir which was the commercial center of İzmir when the Levantine population highly existed between the beginning of the 17 th up to the end of 19th century [9]. Therefore, the area reflects representative examples of the 19th century residential architecture in Izmir [10]. Fig. 1(a) illustrates the position of Izmir and Fig. 1(b) shows the approximate location of Basmane Semt Merkezi [11].

Basmane District was an important commercial area located close by the train station in the 19th century. After that a majority of the hotels around the seaside of İzmir were totally demolished by the 1922 fire, the Hotels Street in Basmane gained significance as a group of hotels reflecting the characteristics of an important period [12].

In the early 19th century, the buildings on the street were designed as residences of merchant class and noble families but used as hotels and accommodation facilities for middle and low income people in the last few decades. Due to the insufficient maintenance and inappropriate interventions over time, the street lost its architectural importance while facing security and social problems. For this reason İzmir-Konak Municipality took a series of decisions and conducted restoration projects to vitalize Hotels Street and emphasize its importance and heritage value [12]. Following the approval of the restoration project by the 'Number 1-İzmir Regional Board for the Conservation of Cultural and

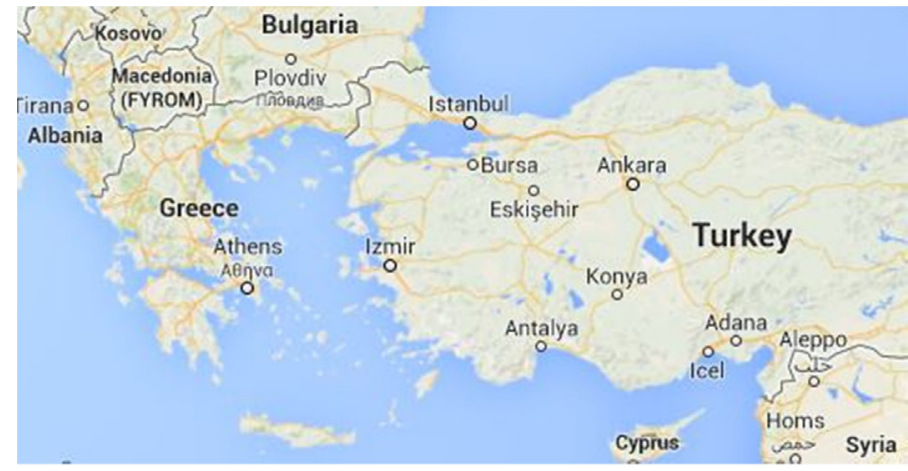

(a)

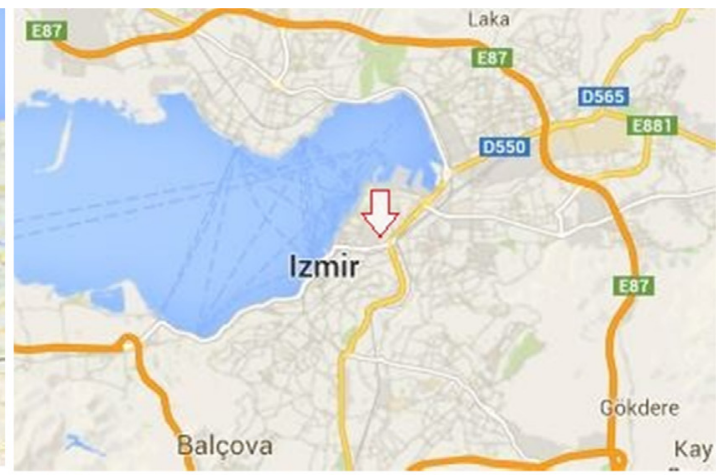

(b)

Fig. 1. Location of (a) İzmir and (b) the location of Basmane Semt Merkezi. 


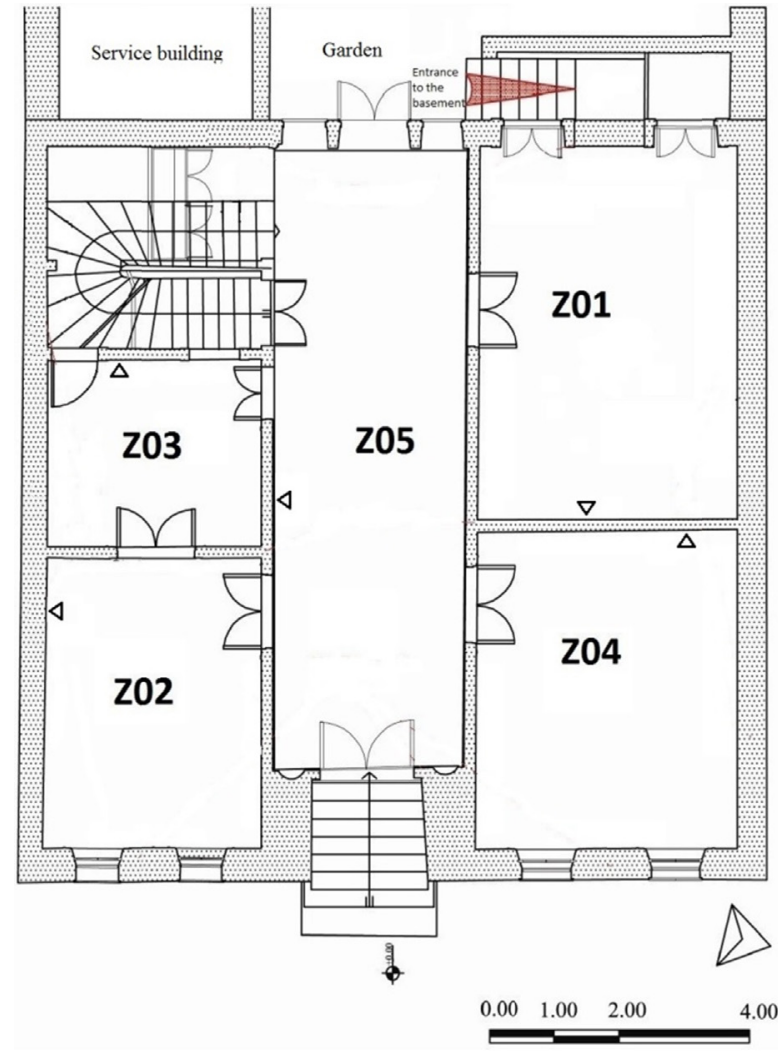

a)

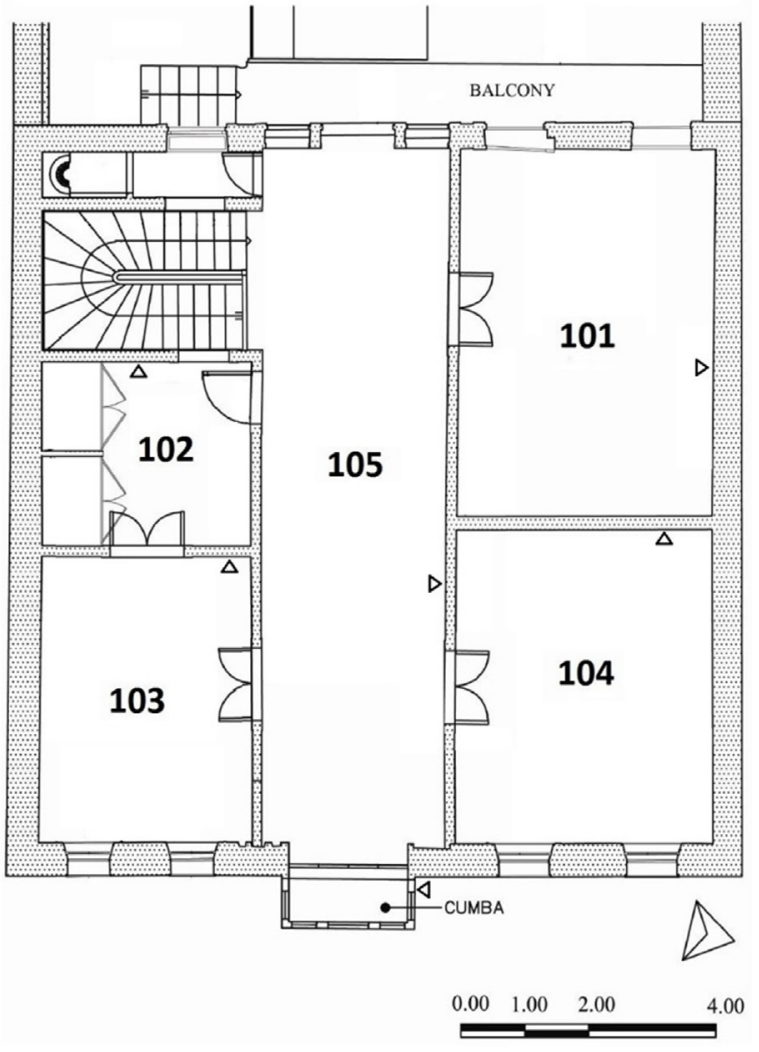

b)

Fig. 2. (a) Ground floor and (b) first floor plan.

Natural Assets', restoration work for Basmane Semt Merkezi was carried out by the use of materials same or compatible with the original ones for the repair or completion of damaged, detached and broken parts of structural components and renderings. Except a fuel-oil boiler unit to be placed in the basement for heating in winter, no additional energy performance measures were proposed. The details of the restoration work and the condition of the building before the restoration is given in Ref. [13].

The west façade of Basmane Semt Merkezi faces to the street numbered 1299 which is connected to the Oteller Sokağl referring to Hotels Street. The street named as Oteller Sokağl is quite narrow, in many parts not more than three meters, and historic buildings are located on both sides.

Basmane Semt Merkezi is a three-story building including the basement. It was built in East-West direction. The west façade faces the garden. There is a service building adjacent to the house at the southeast part of the garden. The connection between the house and the service building is provided only at the ground floor level (see Fig. 2).

The rooms are symmetrically located at the either sides of a longitudinal corridor, at both floors. The wooden stair on the southwest end of house is the only connection between the ground and first floors. Entrance to the basement is provided by the stairs from the garden (see Fig. 2a). Besides, there is a bay window (called cumba) on the east and a balcony on the west edge of the first floor (see Fig. 2b).

\subsection{HVAC system}

Basmane Semt Merkezi has a central heating system but not a cooling and mechanical ventilation system. Therefore, the building is naturally ventilated by occupants when desired. Hereafter HVAC system of the building will only be considered in terms of heating.

The building is heated by a fuel-oil-fired hot water boiler with a maximum capacity of $29 \mathrm{~kW}$, which is located on the basement. The hot water is distributed in the building by a circulation pump (56 W) through a hydronic system with radiators which are located in each room and all have the same dimensions of $60 \mathrm{~cm} \times 120 \mathrm{~cm}$. Heating rate of the radiators is approximately $1.5 \mathrm{~kW}$ at actual average operating conditions which are $22^{\circ} \mathrm{C}$ indoor air temperature and $75 / 55^{\circ} \mathrm{C}$ supply/return temperature [14].

Heating system, which has no thermostat control, is operated manually by the administrator of the building during the working hours (09:00-17:00). For 2012-2013 heating season, it was operated from November 1 st to April 11th. Besides, the radiant electric heaters are used as auxiliary heating sources in the building. The working schedule of the electric heaters depends on the course schedule and occupant behaviour.

\section{Method}

At this stage, the method describing the process, in order to conduct EER in historical buildings, will be explained step by step. First, the building energy simulation (BES) model will be explained in detail. Later, both the significance of calibration of the simulation model and how the calibration work should be done will be given. Finally, the EER scenarios in accordance with the historic heritage values of building will be defined and investigated.

\subsection{Building energy simulation (BES) model}

Basmane Semt Merkezi was modelled along with the neighborhood to quantify the shading effects on solar gain calculations 


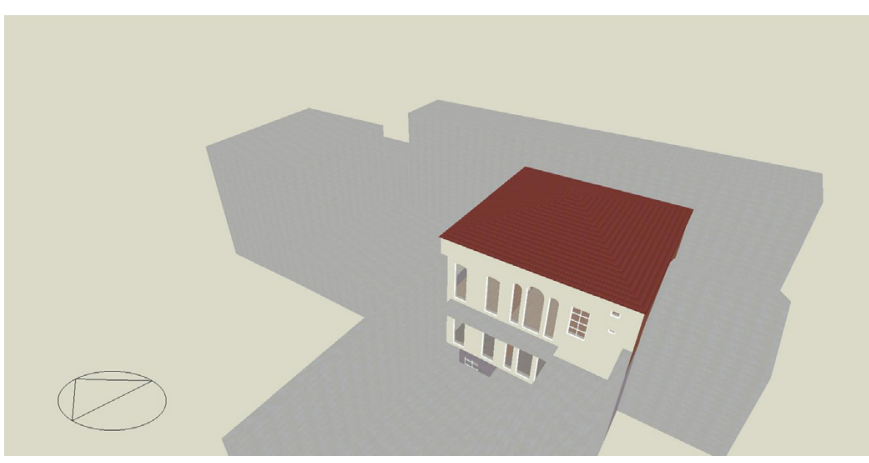

Fig. 3. BES Model of the building and the surroundings.

using the 3D drawing interface of DesignBuilder which was validated according to the "ANSI/ASHRAE Standard 140-2007 Building Thermal Envelope and Fabric Load Tests" [15,16]. Architectural plans and dimensions were obtained from the Department of Architectural Restoration of İmir Institute of Technology and through field surveys.

For a traditional building, the building has a relatively regular geometry as compared to many others with irregular shapes and volumes. Fig. 3 shows the building and its surroundings drawn on the BES tool [15]. Grey colored items illustrate the neighbor buildings. The temperature difference between the adjacent buildings and the case building is assumed to be zero or negligible (adiabatic). The reasons to assume the buildings as adiabatic are to reduce the run time of simulation and those buildings on the north and south sides are also occupied and conditioned.

\subsection{Calibration methodology of the BES tool}

Building energy simulations should be calibrated in order to better reflect the energy consumption of the actual building. In the literature, the most common ways to make a calibration are either to compare the utility bills with the consumption results of the simulation or to make a comparison between the indoor air temperature of measured and simulated data. A suggested way to conduct a simulation calibration is to tune the model by changing the relevant inputs of the models [17]. Flow diagram of the calibration methodology is shown in Fig. 5.

First, indoor and outdoor dry bulb temperatures (DBTs) are measured for the desired time interval. Then, the measured DBTs are integrated with the weather data. Later, the building is modelled and the simulation is run. Simulated results are compared with measured values. If the results are within the error limit specified in the ASHRAE Guideline-14 "Measurement of Energy Demand and Savings", [18] the BES model is assumed to be calibrated. If not, the parameters of the BES model causing the discrepancy are

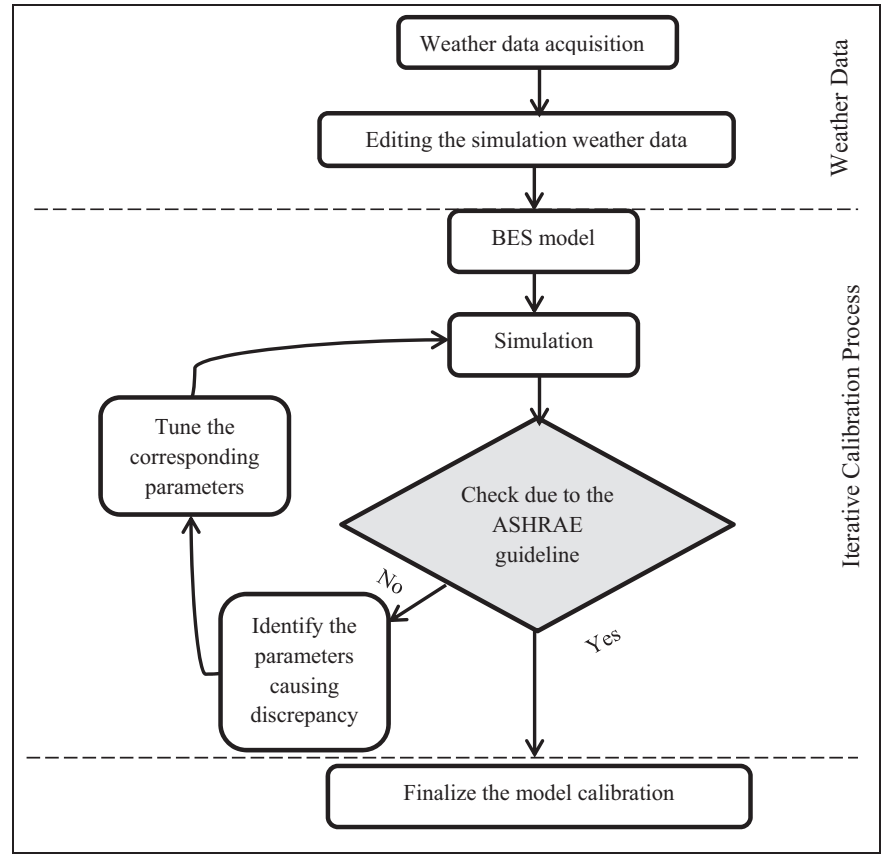

Fig. 5. Flow diagram of the calibration methodology.

identified. These parameters are tuned until the simulation results are within the error limits.

For the calibration, data-loggers were located in each room and outside the building to measure the DBTs for 10 days, between May 28 th and June 6 th, 2013. The location of each data logger was indicated on the building plan with a small triangle (Fig. 2a and b). Data-loggers inside the building were located approximately $2 \mathrm{~m}$ above the floor and all data loggers were placed in a position not to be exposed to direct sunlight.

In the ASHRAE Guideline 14, acceptable tolerances for calibration of the BES model are provided based on mean bias error (MBE) and coefficient of variation of root-mean-squared error (CV(RMSE)) [18]. According to the Guideline, models are assumed to be calibrated if MBE and CV(RMSE) are within $\pm 10 \%$ and $\pm 30 \%$, respectively when hourly data considered. The MBE, RMSE and CV(RMSE) were calculated using Eqs. (1)-(3) [19,20].

$$
\begin{aligned}
& \text { MBE }=\left(\frac{\left(\sum_{i=1}^{n} \text { Residual }_{i}\right)}{n}\right) \% \\
& \text { RMSE }=\left[\frac{\sum_{i=1}^{n}\left|t_{i}-o_{i}\right|^{2}}{n}\right]^{1 / 2} \%
\end{aligned}
$$

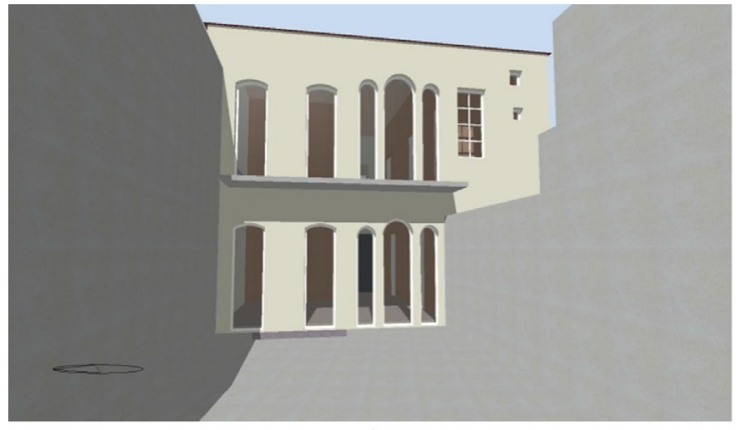

a)

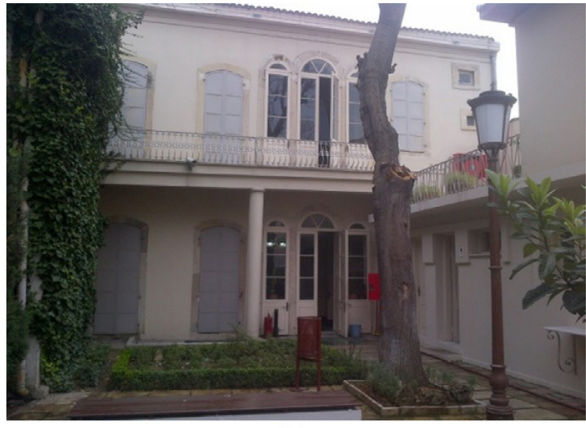

b)

Fig. 4. (a) The BES model and (b) the picture of the west façade. 
$\mathrm{CV}\left(\mathrm{RMSE}_{\text {period }}\right)=\left(\frac{\mathrm{RMSE}_{\text {period }}}{A_{\text {period }}}\right) \%$

\subsection{Retrofitting methodology in historic buildings}

EER in the existing building stock has focused on the thermal envelope of the buildings. External wall insulation and window replacement are commonly proposed EERs to achieve energyreduction targets. Yet at the same time, this might cause the loss of cultural heritage values such as original surfaces, detailing, windows and patina. Such interventions may be destructive for the cultural heritage value of historic buildings. Therefore, EER in historic buildings should not be assessed from mono-disciplinary point of view [21]. In this study, a transdisciplinary approach was used in order to systematically balance the quantitative and qualitative impacts of EER on heritage values [22]. The EER methodology is illustrated in Fig. 6.

According to the methodology, first the building to be investigated should be characterized. Then, targets and their priorities should be well defined. Before the risk and benefit assessment, a long list of retrofits are introduced and assessed in order to eliminate the inappropriate ones due to the assessment criteria. Once the short list of appropriate retrofits is obtained, they are gathered into the packages mainly due to meet the multiple targets. If the results acknowledge the targets, the assessment is terminated. If not, the previous steps are adjusted and iterated in sequence until the required results are obtained.

\subsubsection{Building characterization}

The purpose of characterization is to define the heritage values of the case building. The characterization will focus on energy related components, especially regarding the building envelope such as walls, doors, windows, roof, floors and shutters.

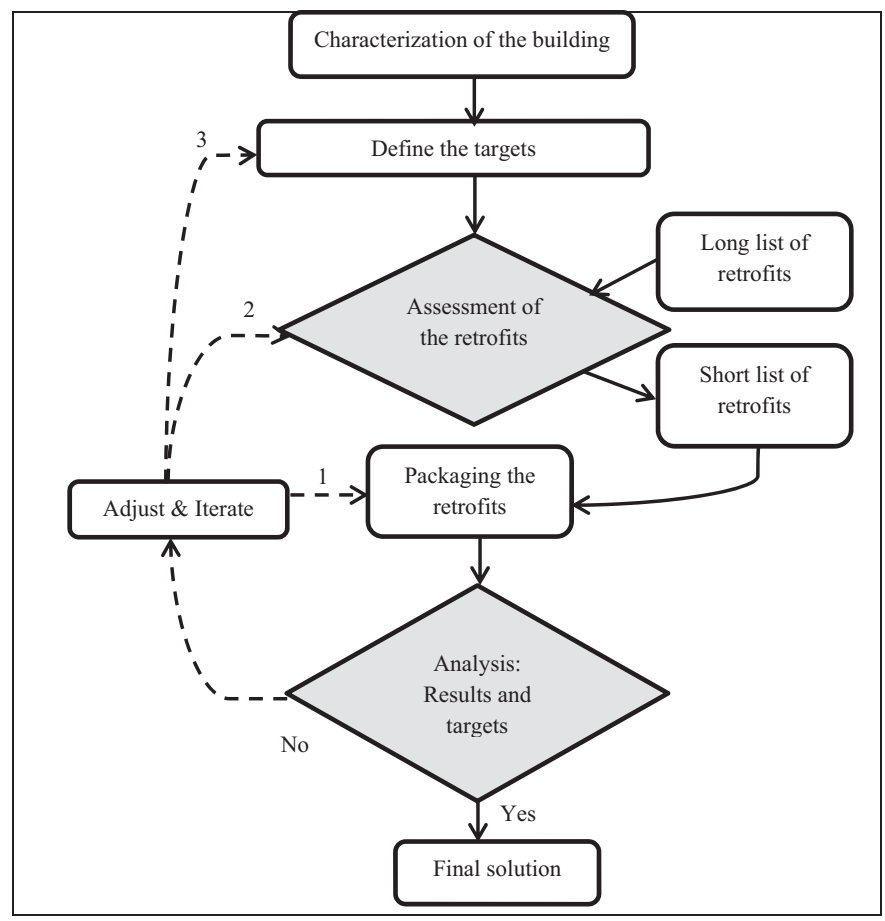

Fig. 6. Retrofitting methodology in historic buildings.

\subsubsection{Targets}

Every EER has objectives, explicit or implicit, in terms of energy and building conservation. In this case study, following targets were selected.

1. Energy saving targets:

a. $20 \%$ reduction in total annual primary energy consumption,

b. $40 \%$ reduction in total annual primary energy consumption.

2. TS 825 [3] requirements for the $U$ values:
a. Wall; $0.70<\mathrm{W} / \mathrm{m}^{2} \mathrm{~K}$,
b. Floor; $0.70<\mathrm{W} / \mathrm{m}^{2} \mathrm{~K}$,
c. Roof; $0.45<\mathrm{W} / \mathrm{m}^{2} \mathrm{~K}$,
d. Windows; $2.40<\mathrm{W} / \mathrm{m}^{2} \mathrm{~K}$.

3. Building conservation targets:

a. Material changes on the construction as minor as possible,

b. No visual change on the building appearance.

Energy saving targets were defined under two options. The first target, which aims 20\% reduction in total annual energy consumption, was inspired from the EPBD while the second one was arbitrarily defined in order to better illustrate the methodology. In case, where multiple targets are defined, the priority of them should be defined. Since building conservation is the primary aim of this study, these targets will be given a higher priority.

\section{Results}

\subsection{Calibration}

Measured outdoor temperature data was integrated with the simulation weather data. For the measurement period, the simulation was run and the results were compared to the measured temperatures of each room. Fig. 7 illustrates the comparison of measured and simulated indoor DBTs for $96 \mathrm{~h}$ period in a sequence within the measured period.

It can be seen from Fig. 7 that measured and simulated data show parallel pattern with small temperature differences throughout the period. For each room, the errors, which are mean bias error (MBE) and coefficient of variance of root-mean-squared-error (CV(RMSE)), between the measured and simulated hourly DBTs are given in Table 1.

According to Table 1 , none of the spaces exceeded neither MBE nor CV(RMSE) limits of ASHRAE Guideline-14. Moreover, energy consumptions regarding electricity and fuel-oil were also compared. Fig. 8 shows the calibration results of the electricity consumption of the building consist of lighting, electrical appliances and auxiliary heating. The comparison denotes that simulation results show similar trend with the energy consumption figures of 2011-2013 on a monthly basis.

Variations in the actual yearly usage figures may be related to the heating degree days (HDD) since the electricity consumption is highly dependent on auxiliary heating. Fig. 9 illustrates the HDD of Izmir for the given years [23]. According to the figure, it is

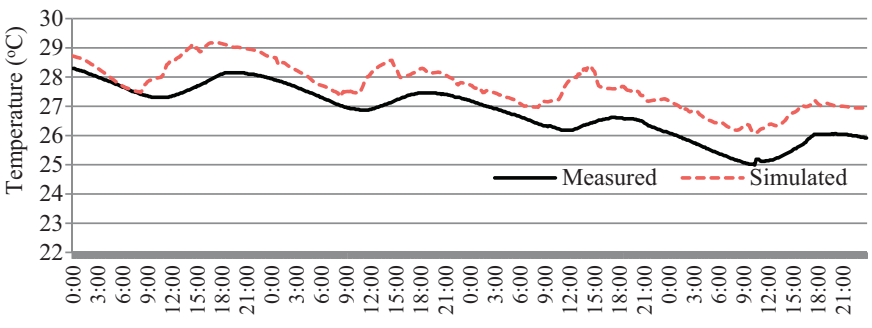

Time

Fig. 7. Comparison of measured and simulated data (Room 102). 
Table 1

Errors for calibration of the BES model for each room.

\begin{tabular}{lcc}
\hline Space & MBE (\%) & CV(RMSE) (\%) \\
\hline Administrator Room (Z01) & 2.0 & 5.2 \\
Classroom (Z02) & 0.5 & 2.2 \\
The Scouts Room (Z03) & 1.8 & 3.4 \\
Guest Room (Z04) & 1.2 & 2.6 \\
Corridor (Z05) & 0.8 & 4.3 \\
Administrator Room (101) & 4.3 & 5.0 \\
Ironing Room (102) & 4.3 & 4.9 \\
Sewing Room (103) & 2.2 & 3.2 \\
Marbling Room (104) & 1.9 & 2.8 \\
Corridor (105) & 5.8 & 6.7 \\
ASHRAE Guideline-14 limit [18] & $\mathbf{1 0}$ & $\mathbf{3 0}$ \\
\hline
\end{tabular}

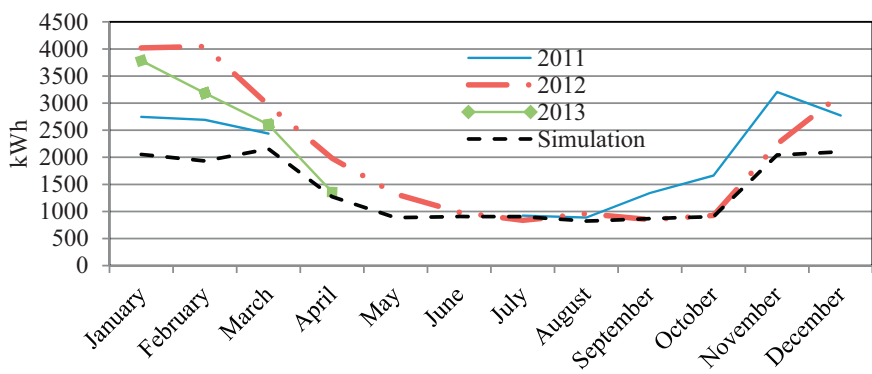

Fig. 8. Comparison of electricity utility bills and simulation results.

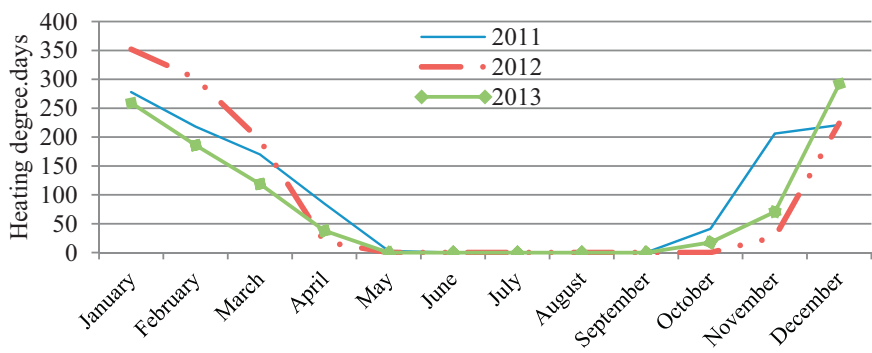

Fig. 9. Heating degree days of İzmir.

possible to say that HDD shows similar pattern with the electricity consumption on both annual and monthly basis. Therefore, the electricity consumption out of the heating season can be interrelated to the lighting and the electrical appliances.

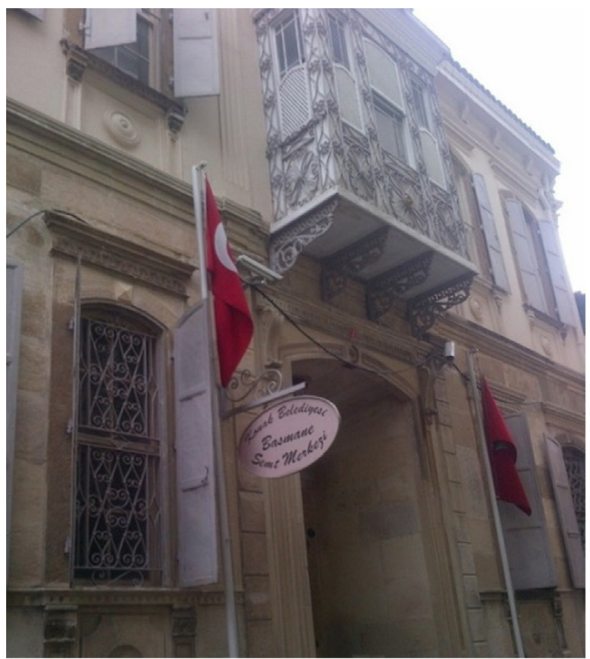

a)
Other criterion for the simulation calibration is to consider the fuel-oil consumption figures. Due to the information obtained from the building administration, the fuel-oil consumption for space heating was not monitored on the monthly basis. Therefore, the calibration was made with respect to the annual figures. The comparison shows that simulation result, $1657 \mathrm{~kg}$ fuel-oil/year, is reasonably close to the actual consumption, $1710 \mathrm{~kg}$ fuel-oil/year.

\subsection{Building characterization}

The rich details of plasterwork and stone claddings with ornamentations on the east façade (Fig. 10a) show that the building was originally built as a typical home for a noble family. The elaborate east façade played an important role in the streetscape. On the contrary, west façade consists of relatively plain texture except the stone casings around the windows and doors (see Fig. 4b). The north and south walls, on the other hand, are rather simply built using either bricks or andesite rubble stone coursed with brick without plaster.

The internal partitions were built using a timber frame with mortared rubble infill (called hımıs technique in traditional timber construction technology in Turkey) which was then plastered and painted. One detail that makes the internal walls valuable is the plaster cornices.

The wooden windows are tangible elements that enrich the building appearance. Wooden frame and single glazed windows with horizontal and vertical dividers all in original materials and forms make them worth to preserve. Fig. 10b illustrates a window example from the building.

The exterior door is made of iron with ornamentations having a considerable impact on the main façade. In addition, doors with wooden frame and crowned with arches placed on the rear façade are other impressive elements perceived from the rich and prestigious garden.

The floor construction shows different compositions on the ground level whilst it is uniform on the first floor. On ground level, the original marble floor is laid out longitudinally enriching the entrance whilst the rooms have a traditional timber floor pattern.

The cumba, which is at the east end of first floor, is a traditional Turkish architectural element with typical wooden framed windows supported and ornamented by iron framework. This is a particular component which adds aesthetic value to the building's main façade (see Fig. 10a).

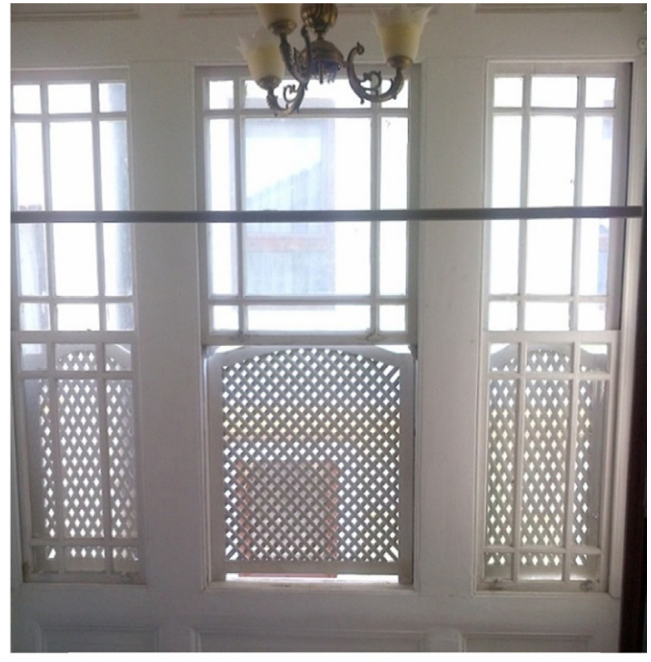

b)

Fig. 10. (a) East façade of the building and (b) the east windows in detail. 
To sum up, it can be said that the building's street façade is characterized by its highly decorated plasterwork and ornamented stone panels, typical for architectural trends of the late 1800's, and the distinguished hand-made cumba supported with cast iron brackets. Any retrofits conflicting with these values would not only harm the building's architectural values, but also, visually separated from the surroundings to some extent. In addition, it is also essential to respect the traditional single glazed windows with their original forms and materials.

\subsection{Assessment of the retrofits}

There is a wide range of possible EER interventions. Based on the literature survey and the applicability of interventions with the BES tool, the following retrofits were, first, chosen for the long list of common interventions which include weather stripping, indoor air temperature control, changing the windows, insulation of the attic floor, additional insulation of the roof, exterior insulation of walls, interior insulation of walls, additional insulation on the ground floor, changing the heating system and/or fuel and finally integration of renewable energy technology.

The risk and benefits of any retrofit can vary depending on the character and heritage values of the building. Therefore, characterization should be done carefully and systematically in relation to a number of aspects [22]. Table 2 summaries the risk-benefit analysis for the case building, Basmane Semt Merkezi.

Air tightness improvement of the building envelope is generally a straightforward and cheap application. It provides high benefits reducing the heat losses occurring through the draughts. On the other hand, it might cause an increased risk for mold growth since the air exchange rate of case building envelope was reduced.

Replacing the existing windows with ones having lower $U$-value would doubtlessly have a high risk on the aesthetic view and heritage values of the case building even though it explicitly reduces the heat losses. From an economic perspective, changing windows have long term pay-back period.

Attic floor insulation, in theory, is expected to be an acceptable solution for the case building due to no damage risk on the building appearance. It, however, jeopardizes the attic environment increasing the moisture as a result of temperature decrease, in practice. Adding extra insulation layer to the roof appears to be low risk for the building fabric since refitting of the roof tiles is a simple application. Moreover, it increases the thermal resistance of the roof and diminishes the heat losses, which is acceptable when considering pros and cons in total.

Even though adding external insulation to the façade is a highly favorable energy efficient retrofit, it would have a strong effect on the building's symbolic values and architectural identity. Therefore, it is considered as inappropriate intervention for this case. Interior wall insulation is relatively less risky when comparing to exterior insulation for building architectural value as long as it is installed carefully. On one hand, it is a great energy saving proposal to keep the heat inside from the perspective of intermittent heating of the case building. On the other hand, it might be problematic for dampness issue due to rapid heating and cooling. Hence, interior insulation might be assessed as acceptable retrofit.

Ground floor insulation is partly available because of its two different floor patterns, timber on the rooms and marble throughout the longitudinal corridor ground floor. Therefore, timber floor seems to be appropriate for the application since there is enough space to install it from below the floor construction.

By the time this study was being undertaken, the building had a hot water radiator system with an old and low efficient fuel-oil boiler placed during the restoration upon the necessities. Therefore, switching it to the high efficient, condensing natural gas boiler is a good refurbishment for reducing operational inefficiencies, energy related carbon dioxide emissions and expenditures. Changing the fuel type and heating system is, thereby, obviously cost effective retrofit although its initial investment is relatively high.

Solar panels are compatible applications for buildings in terms of installation. It is generally controversial and therefore required in depth-analysis to ascertain whether or not it is beneficial [24]. For this case, either it is used for electricity or hot water production, benefits of both will be less than risks for the building since the larger the solar panel area the more the energy production and also the more risk for the building's roof appearance. Thus, solar application is defined as an unacceptable decision.

As a result of risk-benefit assessment, inappropriate retrofits were eliminated, and the short list of retrofits is obtained. In the following section, the appropriate ones will be gathered into packages to meet the targets and evaluate their combined effects on energy consumption.

\subsection{Packaging the retrofits}

For the case building, strengths and threats of the energy efficient retrofits were evaluated through the risk-benefit analysis. Thus short list of the appropriate retrofit applications is as follow:

- Weather stripping

- Indoor air temperature control

- Changing the heating system and/or fuel type

- Insulation of the attic floor

- Additional insulation to the roof

- Interior insulation of the walls

- Additional insulation to the ground floor.

Weather stripping basically refers to air tightening the building envelope by $0.1 \mathrm{ACH}$. With this retrofit, it was aimed to fill the cracks and leaks using appropriate technique and materials. Indoor air temperature control aims to keep indoor environment at $24^{\circ} \mathrm{C}$ and $20^{\circ} \mathrm{C}$ when it is occupied and unoccupied, respectively. Changing the heating system simply indicates installing more efficient boiler, which is driven by natural gas. In all insulation related retrofits, stone wool was proposed as an insulation material.

According to the risk levels, retrofits were gathered into three packages. The retrofits that were assessed as risky and eliminated were also included in a package to better understand ideology of the methodology. Table 3 shows the retrofit packages.

The aim of Package 1 is to meet the energy targets without altering the building appearance and damaging the heritage values. Therefore, the retrofits regarding building's thermal properties were not included within the package. In Package 2, more interventions in terms of improving the thermal performance of the building were included. Package 3 was intentionally grouped in order to determine the maximum possible energy savings. Some inappropriate retrofits were also included in the package in order to better understand the retrofitting methodology.

\subsection{In-depth analysis}

In the building, fuel-oil and electricity are used as energy sources. The fuel oil is used for space heating while electricity is used for auxiliary heating, circulation pump, electrical appliances and lighting. Fig. 11 illustrates the shares of primary energy consumption of the building obtained from the calibrated BES tool, before the retrofitting. The shares were calculated introducing all corresponding input data, such as lighting fixtures, heating system, electrical appliances used in the building and their operation schedule, into the BES tool.

Fig. 11 shows that, the share of lighting accounts for $35 \%$ while heating of the building by fuel-oil is $33 \%$, auxiliary heating is $22 \%$ 
Table 2

Assessment of the retrofits.

\begin{tabular}{|c|c|c|c|c|c|c|}
\hline \multirow{2}{*}{$\begin{array}{l}\text { Short list of } \\
\text { retrofits }\end{array}$} & \multicolumn{6}{|c|}{ Assessment criteria } \\
\hline & $\begin{array}{l}\text { Energy } \\
\text { Savings }\end{array}$ & Economic & $\begin{array}{l}\text { Heritage } \\
\text { Values }\end{array}$ & Durability & Moisture & Indoor env. \\
\hline $\begin{array}{l}\text { Weather } \\
\text { stripping }\end{array}$ & $\begin{array}{l}\text { Reduces heat } \\
\text { loss }\end{array}$ & Cheap & No damage & $\begin{array}{l}\text { Should be } \\
\text { renewed } \\
\text { frequently }\end{array}$ & $\begin{array}{c}\text { Low } \\
\text { moisture } \\
\text { and mold } \\
\text { risk }\end{array}$ & $\begin{array}{c}\text { Minor } \\
\text { Improvement }\end{array}$ \\
\hline $\begin{array}{l}\text { Temperature } \\
\text { control }\end{array}$ & $\begin{array}{c}\text { Reduces the } \\
\text { excessive } \\
\text { heating }\end{array}$ & Cheap & No damage & $\begin{array}{l}\text { Long life } \\
\text { time }\end{array}$ & Beneficial & $\begin{array}{c}\text { Improved } \\
\text { thermal } \\
\text { comfort }\end{array}$ \\
\hline $\begin{array}{l}\text { Changing the } \\
\text { windows }\end{array}$ & Low U value & $\begin{array}{c}\text { Expensive } \\
\text { way, long } \\
\text { payback } \\
\text { period }\end{array}$ & $\begin{array}{c}\text { Negative } \\
\text { impact on } \\
\text { architectural } \\
\text { view, loss of } \\
\text { heritage value, } \\
\text { high risk }\end{array}$ & $\begin{array}{l}\text { Long life } \\
\text { time }\end{array}$ & Neutral & $\begin{array}{l}\text { Improved } \\
\text { thermal } \\
\text { comfort }\end{array}$ \\
\hline $\begin{array}{l}\text { Insulation of } \\
\text { the attic floor }\end{array}$ & $\begin{array}{c}\text { Decreases } \\
\text { heat loss, } \\
\text { medium } \\
\text { benefit }\end{array}$ & Expensive & No impact & $\begin{array}{l}\text { Long life } \\
\text { time }\end{array}$ & $\begin{array}{c}\text { Low } \\
\text { moisture } \\
\text { and mold } \\
\text { risk on the } \\
\text { attic }\end{array}$ & $\begin{array}{c}\text { Minor } \\
\text { improvement }\end{array}$ \\
\hline $\begin{array}{l}\text { Additional } \\
\text { insulation of } \\
\text { the roof }\end{array}$ & $\begin{array}{c}\text { Diminish heat } \\
\text { loss medium } \\
\text { benefit }\end{array}$ & Expensive & $\begin{array}{l}\text { Minor effect } \\
\text { on building } \\
\text { appearance }\end{array}$ & $\begin{array}{l}\text { Long life } \\
\text { time }\end{array}$ & Low risk & $\begin{array}{c}\text { Minor } \\
\text { improvement }\end{array}$ \\
\hline $\begin{array}{l}\text { Exterior } \\
\text { insulation of } \\
\text { walls }\end{array}$ & $\begin{array}{l}\text { High energy } \\
\text { savings }\end{array}$ & Expensive & $\begin{array}{l}\text { High risk on } \\
\text { building } \\
\text { appearance } \\
\text { and heritage } \\
\text { value }\end{array}$ & $\begin{array}{l}\text { Long life } \\
\text { time }\end{array}$ & $\begin{array}{l}\text { Almost no } \\
\text { moisture } \\
\text { risk }\end{array}$ & $\begin{array}{l}\text { Improved } \\
\text { thermal } \\
\text { comfort }\end{array}$ \\
\hline $\begin{array}{l}\text { Interior } \\
\text { insulation of } \\
\text { walls }\end{array}$ & High benefit & $\begin{array}{c}\text { Fairly } \\
\text { expensive, } \\
\text { long pay- } \\
\text { back time }\end{array}$ & $\begin{array}{c}\text { No damage for } \\
\text { the case } \\
\text { building }\end{array}$ & $\begin{array}{l}\text { Long life } \\
\text { time }\end{array}$ & $\begin{array}{l}\text { Should be } \\
\text { breathing } \\
\text { material }\end{array}$ & Beneficial \\
\hline $\begin{array}{l}\text { Additional } \\
\text { insulation on } \\
\text { ground floor }\end{array}$ & $\begin{array}{c}\text { Reduces the } \\
\text { heat losses } \\
\text { from the } \\
\text { basement }\end{array}$ & $\begin{array}{c}\text { Rather } \\
\text { expensive }\end{array}$ & $\begin{array}{l}\text { Might require } \\
\text { special } \\
\text { attention for } \\
\text { installation }\end{array}$ & $\begin{array}{l}\text { Long life } \\
\text { time }\end{array}$ & $\begin{array}{c}\text { Attention } \\
\text { should be } \\
\text { paid for the } \\
\text { basement }\end{array}$ & $\begin{array}{c}\text { Minor } \\
\text { Improvement }\end{array}$ \\
\hline $\begin{array}{l}\text { Changing the } \\
\text { heating } \\
\text { system and/or } \\
\text { fuel }\end{array}$ & $\begin{array}{l}\text { High energy } \\
\text { saving }\end{array}$ & $\begin{array}{l}\text { Expensive } \\
\text { and long } \\
\text { pay-back } \\
\text { time }\end{array}$ & No impact & $\begin{array}{l}\text { Long life } \\
\text { time }\end{array}$ & Neutral & $\begin{array}{c}\text { Minor } \\
\text { Improvement }\end{array}$ \\
\hline $\begin{array}{l}\text { Renewable } \\
\text { energy } \\
\text { sources } \\
\text { (Solar panel } \\
\text { application) }\end{array}$ & $\begin{array}{c}\text { Energy } \\
\text { Production }\end{array}$ & $\begin{array}{c}\text { Fairly } \\
\text { expensive }\end{array}$ & $\begin{array}{l}\text { High risk on } \\
\text { building } \\
\text { appearance }\end{array}$ & $\begin{array}{l}\text { Long life } \\
\text { time }\end{array}$ & Neutral & Neutral \\
\hline & & Represent & meaning of th & colors & & \\
\hline High risk & Low & & Neutral & Low be & fit & ligh benefit \\
\hline
\end{tabular}

Table 3

Energy efficient retrofit packages for the case building (in detail).

\begin{tabular}{|c|c|c|c|c|c|c|}
\hline \multirow[t]{2}{*}{ Retrofits } & \multicolumn{2}{|c|}{ Package 1} & \multicolumn{2}{|c|}{ Package 2} & \multicolumn{2}{|c|}{ Package 3} \\
\hline & Existing & New & Existing & New & Existing & New \\
\hline Weather stripping & \multicolumn{6}{|c|}{$0.1 \mathrm{ACH}$ improvement on the building envelope in general } \\
\hline Heating system (seasonal efficiency) & 0.53 & 0.82 & 0.53 & 0.82 & 0.53 & $\begin{array}{l}\text { COP: } 4.4 \\
\text { (heat pump) }\end{array}$ \\
\hline Thermostat control & \multicolumn{6}{|c|}{ Previously, no thermostat control proposed, $24^{\circ} \mathrm{C}$ for occupied and $20^{\circ} \mathrm{C}$ for unoccupied spaces } \\
\hline Attic floor insulation ( $U$-value) $\left(\mathrm{W} / \mathrm{m}^{2} \mathrm{~K}\right)$ & - & - & 1.1 & 0.41 & - & - \\
\hline Exterior wall insulation ( $U$-value $)\left(\mathrm{W} / \mathrm{m}^{2} \mathrm{~K}\right)$ & - & - & - & - & 1.1 & 0.48 \\
\hline Interior wall insulation ( $U$-value $)\left(\mathrm{W} / \mathrm{m}^{2} \mathrm{~K}\right)$ & - & - & 1.1 & 0.48 & - & - \\
\hline Roof insulation ( $U$-value) $\left(\mathrm{W} / \mathrm{m}^{2} \mathrm{~K}\right)$ & - & - & - & - & 1.5 & 0.42 \\
\hline Ground floor insulation ( $U$-value) $\left(\mathrm{W} / \mathrm{m}^{2} \mathrm{~K}\right)$ & - & - & 1.4 & 0.54 & 1.6 & 0.54 \\
\hline Changing windows ( $U$-value) $\left(\mathrm{W} / \mathrm{m}^{2} \mathrm{~K}\right)$ & - & - & - & - & 3.2 & 1.78 \\
\hline
\end{tabular}

and electrical appliances is $10 \%$. The total heating energy consumption including auxiliary heating has the highest share in total energy consumption of the building followed by lighting and electrical appliances. In order to obtain primary energy consumptions, conversion factors, which are 1 for heating oil, 1 for natural gas and 2.36 for electricity, were taken into account [25].

Fig. 12 shows the comparison of the heating system energy demand, total annual primary energy consumption and its 


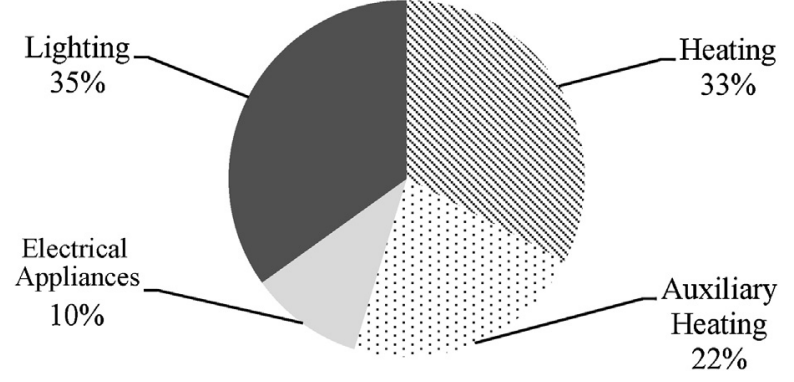

Fig. 11. Shares of total annual primary energy consumption.

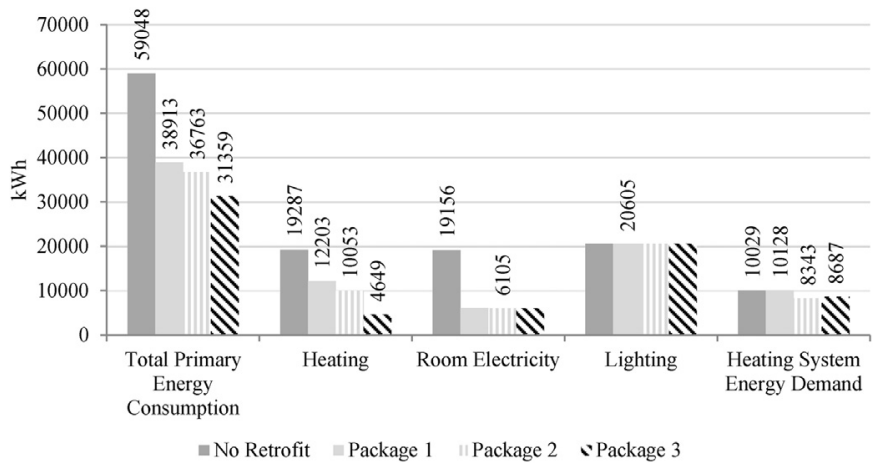

Fig. 12. Comparison of the EER results on package basis.

components of heating, lighting and room electricity (electrical appliances + auxiliary heating), on package basis. At this point, it is necessary to give the definition of heating system energy demand for better understanding. Basically, heating system energy demand is the amount of energy which should be supplied by the heating system to the building in order to keep the indoor environment under the desired conditions.

Results of Package 1 indicate that the annual primary energy consumption decreased while the heating energy demand increased. This is because the auxiliary heating sources were discarded. Despite the positive effect of retrofits on weather stripping and temperature control, discarding the auxiliary heating increased the heating demand. However, the total annual energy consumption reduced due to the more efficient heating boiler. Hence, it can be stated that minor energy reduction target, $20 \%$, was reached without disturbing the building construction and appearance, while the target of $40 \%$ was not. Moreover, the heritage values were conserved while the $U$-value targets inquiring thermal improvements and alterations on the building components could not be met due to the content and aim of Package 1 .

The results of Package 2 show that the heating energy demand and total annual primary energy consumption were reduced with respect to the Package 1 . The main reason for this is the interior insulation, which causes approximately 5\% reduction in energy consumption. According to the results, the minor energy target, $20 \%$, can easily be accomplished while the TS825 standard [3] is partially satisfied. Even the small, reversible constructional changes, the package did not unavoidably affect the building appearance and heritage value so that the conservation targets were also reached.

Package 3 was intended to show the effect of maximizing the energy saving without considering the heritage value, even tangible elements having significant role on building's character were changed such as windows were replaced with ones having double glazing and PVC frame and insulation was applied to the outer walls. The other significant change in the 3rd retrofit package is the use of an air-source heat pump for heating purposes. This retrofit was not included in the 2 nd retrofit package since the primary aim of which was to preserve actual building's heritage value. Each room was individually equipped with split heat pump units having $3.5 \mathrm{~kW}$ average heating power (min. 0.9-max. 5.5) and a COP of 4.4 [26]. The results show that heating demand increased while the energy consumption decreased drastically. The reason of the increase in the heating energy demand can be explained due to the average heating power of heat pump, which is higher than the previous hot water radiators. Yet, total annual primary energy consumption was decreased by $47 \%$ since the high COP of the air source heat pump system compensates the primary energy conversion factor which is 2.36 for electricity.

The results of Package 3 indicate that major energy target, 40\%, can be accomplished only with the destructive and irreversible changes from the building conservation perspective. Changing the prominent heritage values would not only destroy the building appearance but also tangible records and memories that the building has carried for ages.

Furthermore, each single retrofit was simulated to evaluate their individual effect on the energy consumption. Even though discarding the auxiliary heating system was not counted as a retrofit, the impact of it was also included in the evaluation.

Fig. 13 illustrates the cumulative effect of single retrofits based on the primary energy consumption and the package basis. The most effective reduction regarding the energy consumption was obtained by changing the heating system with the air source heat pump, which is by $24.8 \%$. This effect was followed by discarding the auxiliary heating $(14.1 \%)$, natural gas boiler (12.2\%), indoor temperature control (7.1\%), interior wall insulation (4.7\%), exterior wall insulation (3.9\%), weather stripping (1.1\%), roof insulation $(0.9 \%)$, attic floor insulation $(0.7 \%)$, changing the windows $(0.5 \%)$ and finally ground floor insulation $(0.5 \%)$. Therefore, the cumulative effect of the single energy reductions on the package basis corresponds to 35\% for Package 1, 41\% for Package 2 and 53\% for Package 3.

However, the combined effect of the single retrofits is not the same as simply adding them up. Insulation of the external walls, for example, will eventually diminish the single effect of changing the boiler [27]. Fig. 14 shows the comparison of combined and cumulative effect of single retrofits on total annual energy consumption.

Hence, the comparison results indicate that the differences between combined and cumulative impacts are $1 \%$ for the Package 1, 2\% for the Package 2 and 6\% for the Package 3. These discrepancies should not be underestimated when economic calculations are of interest.

In Aegean Region, cooling is of consideration during summer season. Therefore, EER should be assessed both taking into account of heating and cooling energy consumption. Although heating energy consumption is the primary interest of this study, it is favorable to show the impact of EER on cooling load. Fig. 15a and b illustrates the effect of EER packages on heat gains through walls and infiltration, respectively. Hence, it can be said that external insulation (Package 3 ) reduces the heat gains by $63 \%$ which is more than that of including internal insulation (Package 2) even though they have the same insulation thickness. However, Package 3 increases the heat gain via infiltration by 31\% though the same air-tightness value with Package 2 .

Since the case building is located in Aegean Region where is hothumid climate, effect of the EER intervention proposals on cooling load should also be taken into account.

Thermal comfort is another important parameter to be considered when the EER is of interest in historic buildings. Fig. 16 shows the change of thermal comfort (within the heating season) of the space 105 (see Fig. 2b) due to the effect of EER packages, where the comfort zone was shown with a dashed rectangle. 


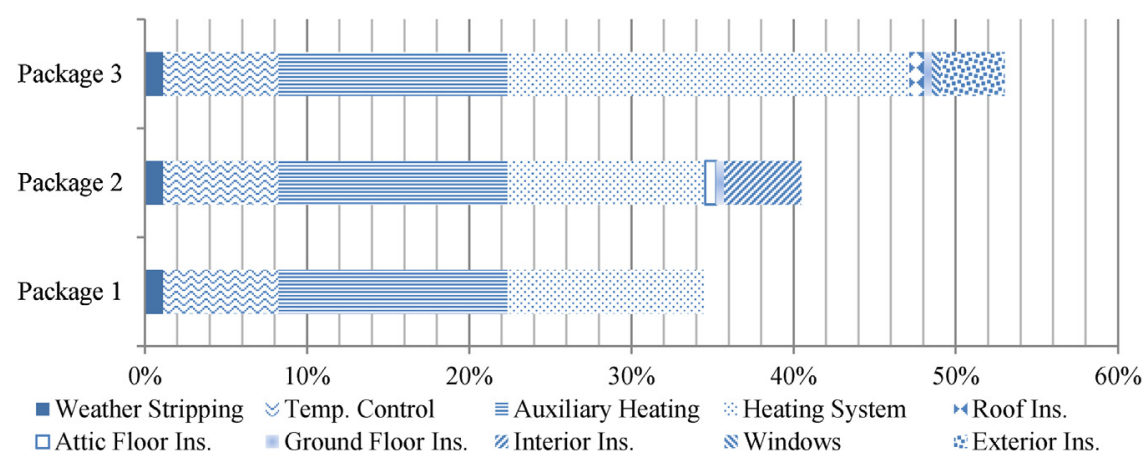

Fig. 13. Cumulative effect of the single retrofits on package basis.

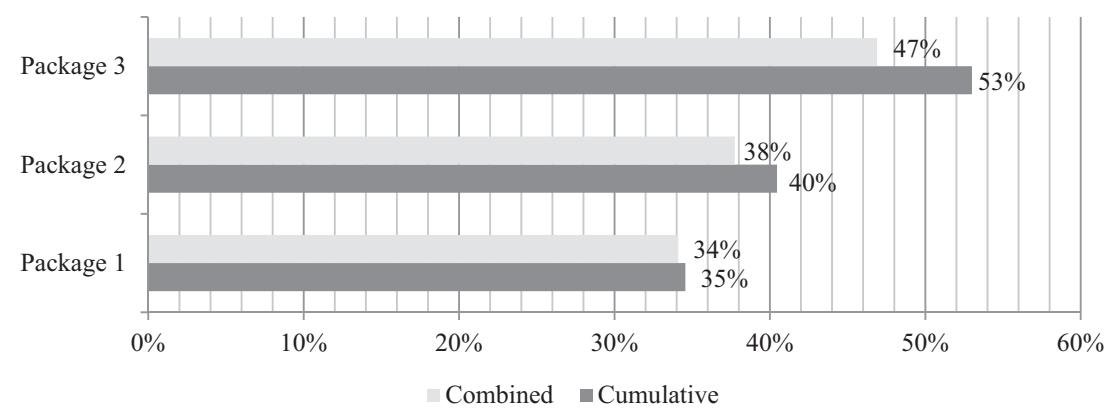

Fig. 14. Comparison of the combined and cumulative effect of the retrofits.

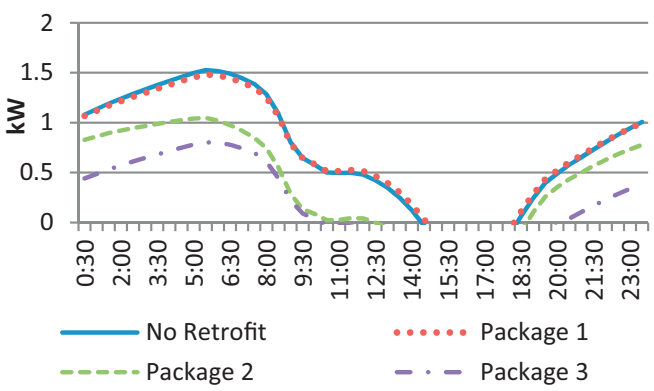

a)

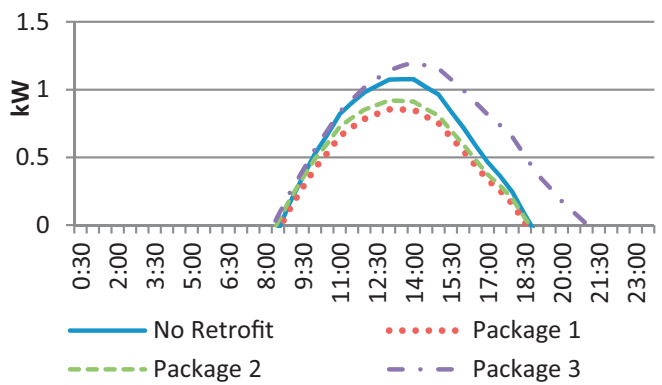

b)

Fig. 15. Effect of EER packages on cooling load; (a) heat gains from the walls, (b) heat gain via infiltration (for July, 15).

In the given space, which is used for an educational purpose, thermal comfort zone is defined as the area where the relative humidity and temperature are between $30-60 \%$ and $20-25.5^{\circ} \mathrm{C}$, respectively [28].

According to Fig. 16, the rate of points within the comfort zone were calculated for each EER packages are $44 \%$ for no retrofit case, $44 \%$ for Package 1, 49\% for Package 2 and $51 \%$ for Package 3 . Hence, it can be said that the thermal comfort within the heating season was improved through the EER packages. Nevertheless, it is seen that some points, which are indicated within two circles, dropped out of the comfort zone. The reason behind the points highlighted within the big circle is that the building has an intermittent heating regime. Thus the indoor air needs to be reheated from the lower temperatures rather than $20^{\circ} \mathrm{C}$, which is the lowest threshold based on ASHRAE Standard-55 [28]. On the other hand, the points in the small circle indicate that the indoor air can be conditioned to acceptable temperature but relative humidity since none of the proposed heating systems have humidity control.

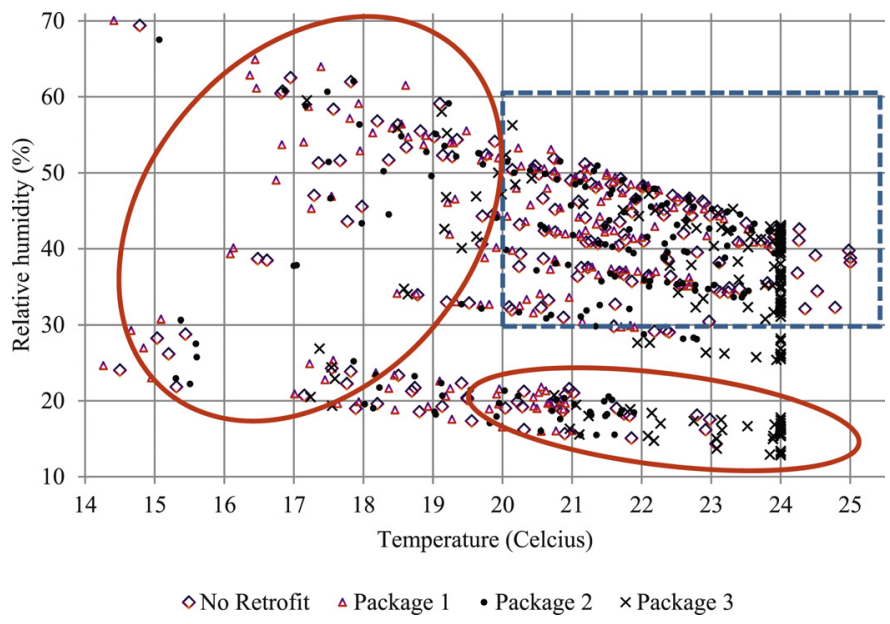

Fig. 16. Change of thermal comfort on package basis (for the space, 105). 
Table 4

Target results.

\begin{tabular}{lllll}
\hline Targets & & Package 1 & Package 2 & Package 3 \\
\hline Energy saving & $20 \%$ & + & + & + \\
& $40 \%$ & - & - & + \\
$U$-value due to the & Ceiling & - & + & + \\
standard TS825 & Floor & - & + & + \\
& Wall & - & + & + \\
& Windows & - & - & + \\
Heritage value and & Construction & + & + & - \\
building physics & Appearance & + & + & - \\
\hline
\end{tabular}

\section{Conclusions}

Historic buildings generally use more energy as compared to the ones built in the recent past. Therefore, one can conclude that instead of leaving them undisturbed and unattended, the buildings carrying heritage values should be treated deliberately and with great awareness to reintegrate their use with modern life.

In this study, EER of a historic case study building was investigated with a step by step, transdisciplinary methodology in order to reduce the energy consumption of the building in heating season without unacceptable impact on the historical heritage values. A validated BES tool was used to model the building and assess the energy consumption of the retrofit scenarios. The model was calibrated in order to determine accurate and reliable outputs from the BES tool.

Based on the literature survey, a number of interventions which are the most common energy efficient retrofits were selected. Following the elimination of inappropriate applications, the interventions were divided into three packages in order to establish a better understanding about the methodology (see Table 3 ).

The results of the case study are summarized in Table 4 in which positive (+) sign denotes the target is reached while the negative $(-)$ one is not.

Thus, it can easily be concluded that the minor and relatively intermediate energy saving reductions can be reached without disturbing the historical, architectural and cultural values while the major energy target cannot. This is a reasonable proof that the transdisciplinary approach used within the methodology was successful and necessary.

As it was indicated in introduction, there is no equivalent study in Turkey that we can compare with the outcomes of the methodology. Therefore, it is favorable to make a couple of distinctive comparison with the similar studies done abroad.

A study conducted in Sweden [22] aimed to balance the energy conservation and building conservation in a multidisciplinary decision context. The results show that $20 \%$ energy saving target seems to be not problematic from building conservation point of view while that of $50 \%$ can only be reached affecting the visual appearance and significance of the building. Another study in Norway [21] focused on the influence of energy-saving measures on heritage buildings taking into consideration of a holistic approach. Results indicated that the measures affecting the exterior appearance have more detrimental impact than those of simple, non-destructive and cheap ones such as weather stripping, improving windows and heat insulation in the basement. Moreover, fuel conversion was concluded to be considerable opportunity for heritage buildings not to change building envelope.

The effects of retrofitting on thermal comfort should be analyzed for the case buildings and it is recommended to take retrofitting measures which include improvements in thermal comfort as well.

The transdisciplinary approach for historic buildings should be considered and emphasized in the directives and laws. It is known that there is a work on developing a new European Standard, called
"Guidelines for improving energy performance of architecturally, culturally or historically valuable buildings" [29]. However, this work should also be conducted and specified for other countries. Remembering that there is no clear guideline regarding energy efficient improvements of historic buildings in Turkey, this issue should be enlightened, clarified and included with the help and liaison of institutional, professional, administrative and practical authorities.

\section{Acknowledgements}

The authors would like to thank Izmir-Konak Municipality and Department of Architectural Restoration of Izmir Institute of Technology for providing the documents and information about Basmane Semt Merkezi. For the methods development, the authors acknowledge the support from the Swedish Energy Agency within the national R\&D program for energy efficiency in historic buildings.

\section{References}

[1] Petroleum British, BP Statistical Review of World Energy, British Petroleum, London, 2013 (June 2013)

[2] European Parliament, EPBD Recast, Directive 2010/31/EU of the European Parliament and of Council of 19 May 2010 on the Energy Performance of Buildings (Recast), Official Journal of the European Union, 2010

[3] TS825-Thermal Insulation Requirements in Buildings (Recast), Turkish Standard, Turkish Standards Institute, May 2008, Available: http://www. mmo.org.tr/resimler/dosya_ekler/cf3e258fbdf3eb7_ek.pdf (in Turkish), (accessed: 20.02.2014).

[4] Directive on Building Energy Performance (BEP Directive), Off. Gaz., Issue: 27075, 5 December 2008.

[5] Turkish Statistical Institute, (TSI), Building permits statistics and rate of changes, Available: 〈http://www.turkstat.gov.tr/PreTablo.do?alt_id=1055〉, (accessed: 23.02.2015)

[6] U. Stritih, E. Osterman, H. Evliya, V. Butala, H. Paksoy, Exploiting solar energy potential through thermal energy storage in Slovenia and Turkey, Renewable Sustainable Energy Rev. 25 (2013) 442-461.

[7] N. Özeler Kanan, The use of building-integrated active systems in order to provide energy gains in historic buildings, in: Ecocity 2009 Papers Book, İstanbul, Turkey, 2009, pp. 306-318 (13-15 December 2009).

[8] Heritage, English, Energy conservation in traditional buildings, 2, Building Services Engineering and Safety Team, London, 2008.

[9] O. Inal, Levantine Heritage in Izmir, Koc University, 2006 (Ph.D. Dissertation).

[10] B. Yardım, S.S. Tunçoku, Dampness problems in a historic house in Izmir, Turkey, Int. J. Archit. Herit. 3 (1) (2009) 1-23.

[11] Google Maps, 2014 〈https://maps.google.com/〉.

[12] M.T. Zeren, Site rehabilitation examples of the city Izmir as the local identity searches, J. Environ. Sci. Eng. 5 (7) (2011) 915-919.

[13] B. Yardım, Examination of Dampness Problems of a Historic House, Department of Architectural Restoration, İzmir Institute of Technology, İzmir, Turkey, 2006 (Master's Thesis).

[14] C.D. Sahin, Energy Efficient Retrofitting of Historical Buildings: A Case Study on the Building of Basmane Semt Merkezi-İzmir, Energy Engineering, İzmir Institute of Technology, İzmir, Turkey, 2013 (Master's Thesis).

[15] Design Builder, Version 3.4.0.041. Available: 〈http://www.designbuilder co.uk/>, (accessed 21.10.2014)

[16] ANSI/ASHRAE, ANSI/ASHRAE Standard 140-2007 Building Thermal Envelope and Fabric Load Tests, Design Builder Version 3.0, ANSI/ASHRAE, 2011.

[17] C. Koranteg, A. Mahdavi, An investigation into the thermal performance of office buildings in Ghana, Energy Build. 43 (2) (2011) 555-563.

[18] ASHRAE, Guideline 14-2002, Measurement of Energy and Demand Savings, American Society of Heating, Ventilating, and Air Conditioning Engineers, Atlanta, GA, 2002

[19] A. Kandil, J.A. Love, Signature analysis calibration of a school energy mode using hourly data, J. Building Perform. Simul. 7 (5) (2014) 326-345.

[20] V.I. Soebarto, Calibration of hourly energy simulations using hourly monitored data and monthly utility records for two case study buildings, Proc. Build. Simul. 97 (1997) 411-419.

[21] E. Grytli, L. Kværness, L.S. Rokseth, K.F. Ygre, The impact of energy improvement measures on heritage buildings, J. Archit. Conserv. 18 (3) (2012) 89-106.

[22] T. Broström, P. Eriksson, L. Liu, P. Rohdin, F. Ståhl, B. Moshfegh, A method to assess the potential for and consequences of energy retrofits in Swedish historic buildings, Hist. Environ.: Policy Pract. 5 (2) (2014) 150-166.

[23] Turkish State Meteorological Service, Heating and cooling degree days, Available: 〈http://www.mgm.gov.tr/veridegerlendirme/gun-derece.aspx?g= merkez\&m=35-00\&y=2014\&a=09), (accessed 21.10.2014). 
[24] T. Broström, K. Svanström, Solar energy and cultural-heritage values, in: World Renewable Energy Conference, vol. 8 (Low-Energy Architecture), May 2011, Linköping, 2011, pp. 2034-2040.

[25] M. Bayram, Personal Communication, Republic of Turkey, Ministry of Environment and Urbanization, 2015 (23.02.2015).

[26] Fujitsu General Ltd., 2012 Product Catalogue, Available: (http://www. fujitsu-general.com/ee/data/support/downloads/aircon/ctlg/ctlg_2012. airconditioners.pdf), p.24, (accessed: 06.01.2015).
[27] J.H. Cluver, B. Randall, Saving energy in historic buildings: balancing efficiency and value, APT Bull. 41 (1) (2010) 5-12.

[28] M. Kuş, C. Okuyan, H. Bulut, H. Bulgurcu, Evaluation of indoor air quality in classrooms: a case study at Harran University, in: Proceedings of 8th International HVAC+R Technology Symposium, May 12-14 2008, İstanbul, 2008, pp. 223-227 (in Turkish).

[29] T. Broström, Personal Communication, 2014, CEN Committee, European Committee of Standards. 